\title{
IS ETHICS A SCIENCE?
}

\author{
By R. B. Brandt
}

An obvious prerequisite for intelligent discussion of the question "Is ethics a science?" is some agreement on what the word "science" is used to mean. I shall simply state briefly what I take the term "science" to mean, with the hope that my suggestion will command rather general assent. I suggest that we use "a science" to refer to any organized body of objective knowledge. It is intended by this definition to exclude commonsense knowledge of particular truths, such as the location of my apartment or the condition of my bicycle or the raw data of the census taker, on the ground that such truths do not comprise an organized body of knowledge. It is intended to exclude fiction (e.g., science fiction, expressions of appreciation of artistic work, exhortations to patriotic sacrifice, expressions of aspirations or ideals, and so on) as not constituting knowledge. I have spoken of objective knowledge, but the term "objective" is not really doing any work. All I mean by objective knowledge is a set of beliefs about some subject matter which are warranted in an appropriate way, through support either by observations or by whatever kind of reflection in the areas of logic and mathematics is taken to be sufficient to support a conclusion. This definition allows, say, engineering to be a science even though the principles it applies are borrowed from physics or chemistry. The definition would allow also that a piece of historical writing is a part of science, just as much as the cosmological part of astronomy; imaginative reconstruction may be only fiction, but when a hypothesis is shown to fit the evidence best I see no reason why it should not be regarded as part of science. One can define "a science" more narrowly, if one likes, say, as the laws and theories which we must believe because they are the only relatively simple laws and theories which explain the data of observation.

R. B. Brandt, professor of philosophy, University of Michigan, Ann Arbor, Michigan 48104, presented this paper at a symposium ("Is Ethics a Science?") during the annual meeting of the American Association for the Advancement of Science, San Francisco, California, January 3-8, 1980.

[Zygon, vol. 15, no. 1 (March 1980).]

(C) 1980 by the Joint Publication Board of Zygon. 0044-5614/80/1501-0001\$00.75 
It may be useful to postpone appraisal of the status of ethics in order to consider briefly the status of the philosophy of science, or the theory of knowledge. If we define "science" narrowly, then the philosophy of science is not itself a science; and neither is the history of science, although speculative generalizations about the development of science, say, about the role of paradigms, may count conceivably as empirical hypotheses and therefore as science even in the narrow sense. But if we are asking whether the philosophy of science is an organized body of objective knowledge (science in that sense), the answer would seem to be affirmative. Consider the question whether a theory can be refuted by a single well-conducted observation. The answer, known at least since Pierre Duhem, is: not at all necessarily. A theory has observational consequences only in view of auxiliary assumptions, and the apparently disconfirming observation may be ignored if one of the auxiliary assumptions is discarded. Or if observation supports a theory the question must be raised in what sense, if any, the observation has made the theory "more probable." In which sense of "probable"? Not in any frequency sense. In the sense that a "rational" person would bet on it, giving higher odds than he would have before the observation was made? Perhaps. But then we have new problems on our hands, for instance, how to define what helpfully is meant by a "rational" man. Bertrand Russell held that favorable observations make a theory more probable in this sense only if it is legitimate to assume the truth of some very general propositions, themselves apparently not susceptible of confirmation in the way particular theories are. These are perfectly legitimate inquiries, and, while the answers to some of these questions may not yet be clear, it seems there must be a correct or incorrect answer to them. When we get a well-supported one, that should count as a part of an organized body of objective knowledge. Incidentally, if one were to say there is no good answer to them, then we should want to inquire in what sense the empirical sciences can claim to be an organized body of objective knowledge. Whatever is the answer to them, we must notice that science itself involves evaluations, appraisals of belief in view of evidence of observation or of competing theories, not to mention judgments about the safety of DNA research or nuclear plants, which bring a part of science close to the kind of evaluation done by moral philosophers.

Value language and Value Discourse

But now let us turn to ethics. Let me call attention to the fact that recognized sciences concern themselves with values. Psychologists 
have done a great deal of work on the development of values in the child, some along rather Piagetian lines, others along more conventional experimental lines. Furthermore, anthropologists and sociologists have concerned themselves with social norms, with the spread of value systems, say, by culture contact, with the influence on value systems of technological changes such as the introduction of "the pill," and so on. But what we want to know is whether what philosophers do, qua philosophers, in the general area of values is to be counted as science-as producing an organized body of knowledge.

One thing we have to say in answer to this question is that moral philosophers do a lot of very different things. One thing they have done is pay careful attention to the ordinary use of ethical language and to the character of ethical debates. Headway certainly has been made on this. You can call it "empirical semantics or pragmatics of ethical discourse," if you like, but the fact is that owing to the work of philosophers we now know a great deal about value language and value discourse than we did fifty years ago. Such matters are subtle, but they should yield to careful observation and theorizing. That work counts as science as much as many parts of linguistics. Again the phenomenology of morality is an area on which philosophers work, asking themselves what the difference is between a person thinking something is wrong-having a moral commitment-and his having a straight aversion to something, or asking what kind of reflection does or may go on when a person's moral values pull him in two directions so that he has to reach some sort of resolution. Again there is a large group of moral philosophers who work on questions such as how the notion of the "consequences" of an action may be defined or the notion of the "alternatives" to an action-both notions important for stating some general ethical theories (and central for so-called rational decision theory) and for stating clearly some theses in legal theory. An analysis of the implications of the several possible definitions is a job of logic, and this particular activity of philosophers is obviously comparable to the work of other logicians and mathematicians. All of this work is of a kind that goes on in the empirical sciences or mathematics, and there is no ground why the honorific title of being "scientific" should be denied to it.

You may say with some justice, however, that moral philosophers themselves always have regarded these activities as only auxiliary to their main pursuit, that of determining what kind of life is worthwhile, what kinds of things are good in themselves, which kinds of action are morally right or wrong, praiseworthy or blameworthy. And, you may say, when moral philosophers come to questions of these sorts what they do is not remotely like what is done by a scientist, 
either a mathematician or an empirical scientist (e.g., a physicist or psychologist). It is familiar talk, heard almost at mother's knee, that science can tell us how to find means which will reach certain objectives but not how to authenticate any objectives. Or again science can tell us how to do what will conform to a given set of moral principles but not how to determine which set of moral principles is correct. Not only does science not tell us how to do these things; nothing else does. It is all a matter of subjective opinion or attitude. Very often this conclusion is supported by a simple piece of logic: It is said that moral or value principles have predicates like "is a good thing" or "is a desirable thing" or "is morally wrong." Now, it is said, no premises which merely describe observations can contain in principle any such predicates. So no deductive or inductive argument from experimental premises will entail any such value conclusions. So empirical evidence cannot support any moral or value judgment. So do we not have the conclusion that the central part of ethics is no example of objective knowledge at all?

This conclusion is premature. Let us notice that if what theory is "best" or "most justified" in science is a matter of objective knowledge, then which goal, or morality, is "best" or "best justified" may be a matter of objective knowledge too-at least the words are the same, and the concepts and conceptual background may be very much the same.

Let us begin with basic values or desires. The assumption of many social scientists is that no serious reason can be given for regarding some values of some persons as mistaken. But I suggest there is excellent scientific reason for thinking this is not so. Of course people do have different values: Some aspire to contribute to science, others to be long-distance runners. There is no reason why there should not be these differences; nor need we try to adjudicate between them. But one thing we can do is show that some wants are more important for everyone; for instance, we know that a person cannot be a longdistance runner without food; so a welfare program should provide food but maybe not the best-quality running shoes. Again for individual persons it is manifest that the achievement of some desires is much more important than that of others; for instance, a congressman in his rational moments will recognize that his desire for alcohol must step aside if its satisfaction stands in the way of his political career. But we can know also, by leaning on the psychology of motivation, that some values are mistaken. How? Clearly we know that some people are pathologically fearful of harmless snakes, that others refuse to ride on airplanes when their attitudes are costly to them. We think these attitudes are plain irrational; we call them irra- 


\section{R. B. Brandt}

tional fears. But some values are equally irrational. For example, as a result of conditioning, some persons value achievement basically because they think it buys them affection. In some cases the attitude has been produced by middle-class parents showering them with affection when they brought home good report cards and treated them coldly when they came home with Cs. It is a fear of being unloved that is basic, and the achievement value has been produced by conditioning on the assumption that achievement avoids being unloved. Here the factual assumption is a mistake, and we have to say then that the value is a mistake. Or a person may feel uncomfortable about taking time off and enjoying himself because he once wrongly thought that God and his parents wanted him to work and avoid indulgence. Or a person may acquire an aversion to a low-prestige occupation from observing his parents expressing pity for parents of his peer who went into that occupation. And so on. It appears that these values are manifestly mistaken in a way in which aversions to pain, cold, thirst, the absence of human company, and insult or rejection by others are not. So cannot we then say that these values are mistaken and subject to criticism?

We can know also that actions can be mistaken. Again, leaning on the psychology of motivation or theory of action, we can know that an agent would not have done what he did if he had thought of more attractive options open to him, or if he had thought through the details of the expected outcomes of his actions and noticed some undesirable features, or if he had been aware of the true probability that a certain outcome would occur if he acted as he did, or if he had not allowed the insistence of desire for what is immediately available to cloud his perception of better things to come if only he would wait. In other words, we know that if his relevant beliefs had been correct he would have acted differently. Why should we not say then that his actions are subject to objective criticism? Indeed there is a branch of economics called "rational decision theory" which does set standards for criticism of much this sort. When dressed up with the learning and formidable mathematics of an L. J. Savage or of an H. Raiffa and an R. D. Luce, this passes as a part of science. You may say that they are talking only of what conduct is "rational," but whether you call it "rational" or "desirable" the concept is the same; and the real question is whether the ill-advisedness of behavior, from an agent's own point of view, can be a matter of objective knowledge. Of course it can be.

\section{MORAL PRINCIPLES}

Let us turn now to perhaps the hardest problem, that of the status of moral principles. It seems very natural to say that these cannot be 
proved or disproved either by pure logic or by inductive inference from observation. So is there nothing we can do in their appraisal? Obviously there is something we can do, although we may overlook the importance of it. We can ask whether a certain kind of moral code is a good thing or a harmful one, that is, whether it would engage the preference and support of informed and rational persons. Suppose we ask whether it is a good thing in that sense-a thing that rational persons would want for their society-for a person to feel guilty about enjoying himself on the Sabbath day, or to feel guilty about homosexual contacts when he can enjoy no other kind of sex, or to feel guilty about smoking pot or even using cocaine if these are actually harmless, or to feel so much moral revulsion about the idea of suicide that he undergoes untold agony that can be avoided. It is obvious, or at least would be if we went over the details of the analysis, that a moral code which made people feel guilty in these ways would not engage the support of rational people: It is pointless, and it causes needless suffering. But suppose by contrast we ask whether rational persons would want a moral system in which people feel guilty about assaulting others without provocation, or about letting others go hungry when something can be done about it, or about insulting or humiliating others, or about theft or deception or rape or discrimination on grounds of sex or race or age. I suggest that a little analysis will show that a rational person will want people to feel guilty about these things (because feeling guilty will improve their future motivation) and, even better, will want them to be strongly motivated not to do these things. A moral code is an instrument of social control or guidance, such as the legal system, and it is to be judged by its fruits or more exactly by whether it can command the support or preference of fully informed rational persons. It turns out that such persons do not want to have people restrained by conscience from doing what they want to do and would enjoy doing, to no purpose; and they do want them restrained by conscience from behaving in ways which are harmful to others or perhaps also to themselves. So it seems to me that our views about the relative merits of moral systems are open to solid objective appraisal.

If I am right in all this, then what is the scientific status of "normative ethics," that is, the activity concerned with adjudicating among objectives, courses of action, and moral systems? Ethics is a science in the broad sense of being an organized system of objective knowledge, doubtless not nearly as firmly based as some parts of physics but at least as firmly based as most parts of social or clinical psychology. To some extent, however, it is an applied science such as engineering; it must lean on the results of some parts of psychology, sociology, and economics. But incidentally some of these must lean on it: When 
economists talk of rational decisions or interpersonal comparisons or the concept of welfare they had better talk to some philosophers. Normative ethics then is the science of appraisal of actions, aspirations, and moral systems.

There is, however, another side to ethics. We can see this if we ask ourselves why many people have thought that ethics is totally different from the sciences, a matter of subjective opinion, a matter of attitudes. Here a little speculation on intellectual history is in order. Human thought for centuries has been imposed upon by the Platonic conception of a vision of the good; people did not read Aristotle very carefully, or if they did they found Plato more exciting. Human thought has been imposed upon also by a theological conception: that there is a God who has purposes for man, that the good of man is conformity to God's will, and that the right is obedience to divine commands. Human thought has been imposed upon also by language, by the fact that "is a good thing," "is a desirable thing," and "is morally right" came somehow to be phrases in our language which were cut off from the everyday world of human desires, suffering, the criticism of pointless moral codes, and so on. Doubtless a reason for this was the existence of the Platonic and theological traditions. However that may be, as a result of the severing of these various concepts from the everyday concepts of experience, it seemed that it must be impossible to know what is good or desirable or morally right except by some special kind of intuition. Now that pointless severance of these concepts from life needs to be repaired, and repairing it is a task of ethics-the practical task, if you like, of clarifying our concepts or of reformulating our conceptual framework through an understanding of what is going on. This task is one which the philosopher can and should do, and for it he need not rely on the other sciences; this is the traditional task of philosophy, recognized since Socrates, that of clarifying the human conceptual framework. What the moral philosopher can do in pursuit of this goal is to lay out before people what the situation is - what it is to have desires, what it is to be a moral code, and in what ways these may be criticized-and ask them to consider whether they want to know anything different, when they ask what is worthwhile, from knowing what they would want if they were fully informed, not making any cognitive mistakes, and whether they want to know anything different, when they ask if an act is morally right, from whether the act would be permitted by a moral code they themselves would support for society if they were fully informed and rational. We cannot know in advance how everyone would respond to such questions in this context. But clearly what is needed to solve the problem is just more clarity about what it is we 


\section{ZYGON}

would like to know. A tradition of activity of much this sort stretches from Socrates to Russell and Ludwig Wittgenstein. This kind of activity is important and critical for human understanding. You may ask whether this kind of activity is to be called a "science" even in the broad sense. Possibly not, but, if not, then there is an important intellectual activity which falls outside the scope of science.

\section{Timely Reading on Christian Responsibility...} Science and Our Troubled Conscience

By J. ROBERT NELSON. Squarely facing the questions raised by modern science, this challenging new book shows how the resources of Christian faith can serve to guide persons of differing cultures and nations toward a "just, participatory, and sustainable society."

$\$ 6.95$ paper

The official report of the 1979 W.C.C. conference-

\section{Faith and Science in an Unjust World}

Volume 1: Plenary Presentations

Edited by ROGER L. SHINN. This first volume includes contributions from scientists, theologians, and philosophers on Basic Issues, Perspectives and Futures, Particular Problem Areas, and Participation and Power.

$\$ 12.95$ paper

\section{Faith and Science in an Unjust World}

\section{Volume 2: Reports and Recommendations}

Edited by PAUL ABRECHT (also editor of Faith, Science and the Future, $\$ 3.95$ paper). This second volume presents ten reports that show how the conference at MITwas able to relate the issues of faith, science and technology to the societal concerns of the Council.

$\$ 6.95$ paper

\section{今 FORTRESS PRESS}

